\title{
Occupational exposure to welding gases during three welding processes and risk assessment by SQRCA method
}

\author{
Karimi Zeverdegani S, $\mathrm{PhD}^{1}$, Mehrifar Y, MSc Student ${ }^{2}$, Faraji M, MSc Student ${ }^{3}$, \\ Rismanchian $\mathrm{M}, \mathrm{PhD}^{1^{*}}$ \\ 1- Assistant Prof, Dept. of Occupational Health Engineering, School of Health, Isfahan University of Medical Sciences, \\ Isfahan, Iran. 2- MSc Student, Dept. of Occupational Health Engineering, Student Research Committe, School of Health, \\ Isfahan University of Medical Sciences, Isfahan, Iran. 3- MSc Student, Dept. of Occupational Health Engineering, School of \\ Health, Isfahan University of Medical Sciences, Isfahan, Iran.
}

\begin{abstract}
Received: August 2017, Accepted: September 2017

Background: Hazardous chemical agents in the welding operation are a mixture of metal fumes and toxic gases, the inhalation of which causes adverse health effects among welders. The emission of gases in the workplace is a logical cause for concern regarding the potential development of respiratory disease. The aim of the present study was to determine the concentration values of gases discharged during arc welding and perform risk assessment through semi-quantitative chemical risk assessment (SQCRA) method.

Materials and Methods: This cross-sectional study was conducted in an Iranian steel mill on the 3 processes of plasma arc welding (PAW), submerged arc welding (SAW), and gas tungsten arc welding (GTAW). Direct reading instruments were used for sampling of carbon dioxide $\left(\mathrm{CO}_{2}\right)$, carbon monoxide $(\mathrm{CO})$, nitrogen monoxide $(\mathrm{NO})$, nitrogen dioxide $\left(\mathrm{NO}_{2}\right)$, and ozone $\left(\mathrm{O}_{3}\right)$. SQCRA method was used for risk assessment of gases.

Results: The concentrations of $\mathrm{O}_{3}(0.356 \mathrm{ppm}), \mathrm{CO}$ (41.642 ppm), $\mathrm{NO}(6.357 \mathrm{ppm})$, and $\mathrm{NO}_{2}(4.871$ ppm) were found to exceed their threshold limit values (TLVs), while the concentrations of $\mathrm{CO}_{2}$ (3879.285 ppm) were below its TLV. The maximum exposure concentration of all gases, except $\mathrm{CO}_{2}$, was observed in SAW. SQCRA method showed that among the gases, the highest and least risk rating was related to ozone and nitrogen monoxide, respectively. The risk rating for $\mathrm{CO}_{2}, \mathrm{CO}$, and $\mathrm{NO}_{2}$ was low, high, and very high, respectively.

Conclusions: In this study, exposure values were higher than the threshold limit values-time weighted average (TLV-TWA) and the results of risk assessment showed that control engineering should be applied and the use of respiratory protective equipment (RPE) should be made mandatory for welders especially in SAW, PAW, and GTAW processes.
\end{abstract}

Keywords: Welding, Exposure, Gases, Steel

\section{Introduction}

Welding is an important occupational activity worldwide and includes workers in many industries, especially in the manufacturing, steel, and energy industries. Welding is a common process used to join metals by heating them to welding temperature (1). The US Bureau of Labor Statistics estimated that in excess of 330000 US workers do welding as part of their jobs. About two-thirds of those workers were in manufacturing industries (2). In this sector, there are about 730000 full time welding jobs and 5.5 million welding related jobs in Europe (3). In 2008, About 2.34 million people were killed in work-related accidents, 2.02 cases of which were due to work-related diseases (4). Welding produces multiple hazards during operation, including fumes, gases, and physical agents such as extreme heat and ultraviolet radiation. A review by Antonini et al. detailed a number of occupation

* Corresponding author: Masoud Rismanchian, Dept. of Occupational Health Engineering, School of Health, Isfahan University of Medical Sciences, Isfahan, Iran E-mail: rismanchian@hlth.mui.ac.ir 
related adverse health effects in welders, such as lung disease and possible neurological disease (5). Chemicals have different toxicity, and risk assessment of chemicals determines the risk levels that they present to users (6).

Several studies, generally performed in large companies and focusing on atmospheric exposure of welders to particulate matter and metals, have characterized the main determinants of external exposure to be the welding process, ventilation, working in confined spaces, and the composition of consumables $(7,8)$. In contrast, very few risk assessment studies have been performed on gases and conditions of exposure in small and medium-sized enterprises (SMEs) are seldom available (9). Several gases including ozone $\left(\mathrm{O}_{3}\right)$, nitrogen oxides $\left(\mathrm{NO}_{\mathrm{x}}\right)$, carbon monoxide $(\mathrm{CO})$, and carbon dioxide $\left(\mathrm{CO}_{2}\right)$ are generated during arc welding operations (10). Ozone $\left(\mathrm{O}_{3}\right)$ is produced in a photochemical reaction induced by ultraviolet light with atmospheric oxygen gas during the welding process. Ozone is produced within 30 seconds during welding. However, the length of time that $\mathrm{O}_{3}$ remains in the air after welding is completed (postwelding) is unknown (11). Findings have shown that $\mathrm{O}_{3}$ alters pulmonary morphology, physiology, and biochemistry, and it also is a proven cause of asthma in humans (12). $\mathrm{O}_{3}$ is a strong oxidant that generates reactive oxygen species (ROS) in tissues, and even causes DNA damage (13). Welding operations producing comparatively high concentrations of ozone $\left(\mathrm{O}_{3}\right)$ can cause occlusive impairment of the welders' bronchioles (14).

Carbon monoxide (Co) is a lethal poison and can overcome the exposed individual without warning because it is colorless, tasteless, odorless, and non-irritating. Overexposure to CO inhibits the body's red blood cells from carrying sufficient oxygen to other body tissues, which results in asphyxiation. Symptoms of overexposure include pounding of the heart, a dull headache, flashes before the eyes, dizziness, ringing in the ears. High concentrations may become rapidly fatal without producing significant warning symptoms. The effects are also more severe in people who are working hard and in places where the temperature is high (4).

Carbon dioxide $\left(\mathrm{CO}_{2}\right)$ is primarily a colorless, odorless gas. In the earth's atmosphere, it acts as a "greenhouse gas" which plays a major role in global warming and anthropogenic climate change. Human activities are altering the carbon cycle and have contributed substantially to climate change by adding $\mathrm{CO}_{2}$ and other heat trapping gases to the atmosphere. With a global radiative forcing of $1.74 \mathrm{~W} / \mathrm{m}^{2}, \mathrm{CO}_{2}$ is the largest contributor among well-mixed long-lived greenhouse gases, accounting for more than $63 \%$ of the total (15). Exposure to high concentrations of oxidant gas, nitrogen dioxide $\left(\mathrm{NO}_{2}\right)$ and nitrogen monoxide (NO), can induce pulmonary disorders such as acute inflammation and pulmonary edema $(16,17)$. Welding is an important process in the steel industries and has crucial impact on the economy of countries. Therefore, its welders are exposed to chemical agents.

In general, managing health and safety risks at workplaces involves identifying hazards, risk assessment, risk control, and reviewing control measures (18). The risk assessment process includes many phases including hazard identification, exposure assessment, and risk characterization. Risk assessment is a useful tool to improve occupational health and safety policies and the decision-making process for control approaches (19). The aim of the present study was to determine the concentration values of gases discharged during different processes in arc welding and perform risk assessment through semiquantitative chemical risk assessment (SQCRA) method for exposer to welding gases in an Iranian steel mill.

\section{Material and Methods}

This cross-sectional study was performed on the welders at a steel mill in 2017. Welders were selected through census method from welding stations $(n=21)$. The 3 welding 
stations selected were related to welding processes commonly used in the steel industry including plasma arc welding (PAW), submerged arc welding (SAW), and gas tungsten arc welding (GTAW).

The concentrations of ozone $\left(\mathrm{O}_{3}\right)$, carbon monoxide $(\mathrm{CO})$, carbon dioxide $\left(\mathrm{CO}_{2}\right)$, nitric oxide (NO), and nitric dioxide $\left(\mathrm{NO}_{2}\right)$ were measured with direct reading instruments known as real time instruments including detector tubes (GASTEC Corporation, Japan) and piston pump (Gastec GV-100-S-TR, GASTEC Corporation, Japan). The SQCRA method, which was proposed by the Occupational Safety and Health Division of the Ministry of Manpower of Singapore (19), was used to determine chemical exposure risks. This method involves identifying harmful pollutants, hazard rate (HR), and exposure rate (ER), and determining the level of exposure risk. After the identification of the hazardous and common gases in the welding process, the hazard coefficients of and exposure to these gases were determined using the relevant tables and the results of measured values from the work environment were determined. From the square root of the multiplication of risk degree to exposure risk (the following formula), the numerical value of the risk was calculated.

Risk $=\sqrt{H R \times E R}$

Finally, the exposure risk was determined by considering the five levels of negligible $(\mathrm{N})$, low $(\mathrm{L})$, moderate $(\mathrm{M})$, high $(\mathrm{H})$, and very high (VH). SPSS software (version 21, IBM Corporation, Armonk, NY, USA) was used for statistical analysis. The level of significance was considered as $\mathrm{P}<0.05$.

\section{Results}

In this study, the 3 welding processes of SAW, PAW, and GTAW were studied. Average exposure values were significantly lower than the threshold limit values-time weighted average (TLV-TWA) recommended by the American Conference of Governmental Industrial Hygienists (ACGIH) for $\mathrm{CO}_{2}$ and NO. Average exposure values of gases, except $\mathrm{CO}_{2}$, were significantly higher than TWATLV in all welding processes $(\mathrm{P}<0.05)$. Results showed that the measured values for $\mathrm{NO}_{2}(4.87 \pm 1.07), \mathrm{O}_{3}(0.36 \pm 0.14)$, and $\mathrm{CO}$ $(41.64 \pm 6.69)$ were 25,7 , and 1.66 times that of TLV-TWA, respectively. The maximum exposure concentration of all gases, except $\mathrm{CO}_{2}$, was observed in SAW (Table 1).

Table 1: Time-average concentrations of gases during the welding operation

\begin{tabular}{|c|c|c|c|c|}
\hline \multirow[b]{3}{*}{ Gases } & \multicolumn{4}{|c|}{ Gas concentrations in welding processes (ppm) } \\
\hline & GTAW & SAW & PAW & Total \\
\hline & Mean \pm SD & Mean \pm SD & Mean \pm SD & Mean \pm SD \\
\hline $\mathrm{CO}$ & $35.00 \pm 9.14$ & $44.00 \pm 11.20$ & $30.00 \pm 12.80$ & $41.64 \pm 6.69$ \\
\hline $\mathrm{CO}_{2}$ & $4600.00 \pm 1050.30$ & $2456.36 \pm 231.60$ & $3500.00 \pm 816.00$ & $3879.28 \pm 1245.49$ \\
\hline NO & $6.51 \pm 1.70$ & $10.00 \pm 3.31$ & $2.00 \pm 0.80$ & $6.36 \pm 4.37$ \\
\hline $\mathrm{NO}_{2}$ & $5.00 \pm 1.93$ & $5.21 \pm 1.50$ & $3.50 \pm 1.10$ & $4.87 \pm 1.07$ \\
\hline $\mathbf{O}_{3}$ & $0.40 \pm 0.08$ & $0.42 \pm 0.12$ & $0.16 \pm 0.04$ & $0.36 \pm 0.14$ \\
\hline
\end{tabular}

GTAW: Gas tungsten arc welding; SAW: Submerged arc welding; PAW: Plasma arc welding $\mathrm{P}<0.05$

The results of SQCRA method (Table 2) showed that SAW, PAW, and GTAW had a very high $(\mathrm{VH})$ rank in terms of risk of exposure to ozone and nitrogen dioxide. SAW and GTAW had a high $(\mathrm{H})$ rank in terms of risk of exposure to monoxide nitrogen. Among the gases studied, maximum rank of risk related ozone $(R R=5)$. 
Table 2: The results of risk assessment for welding gases

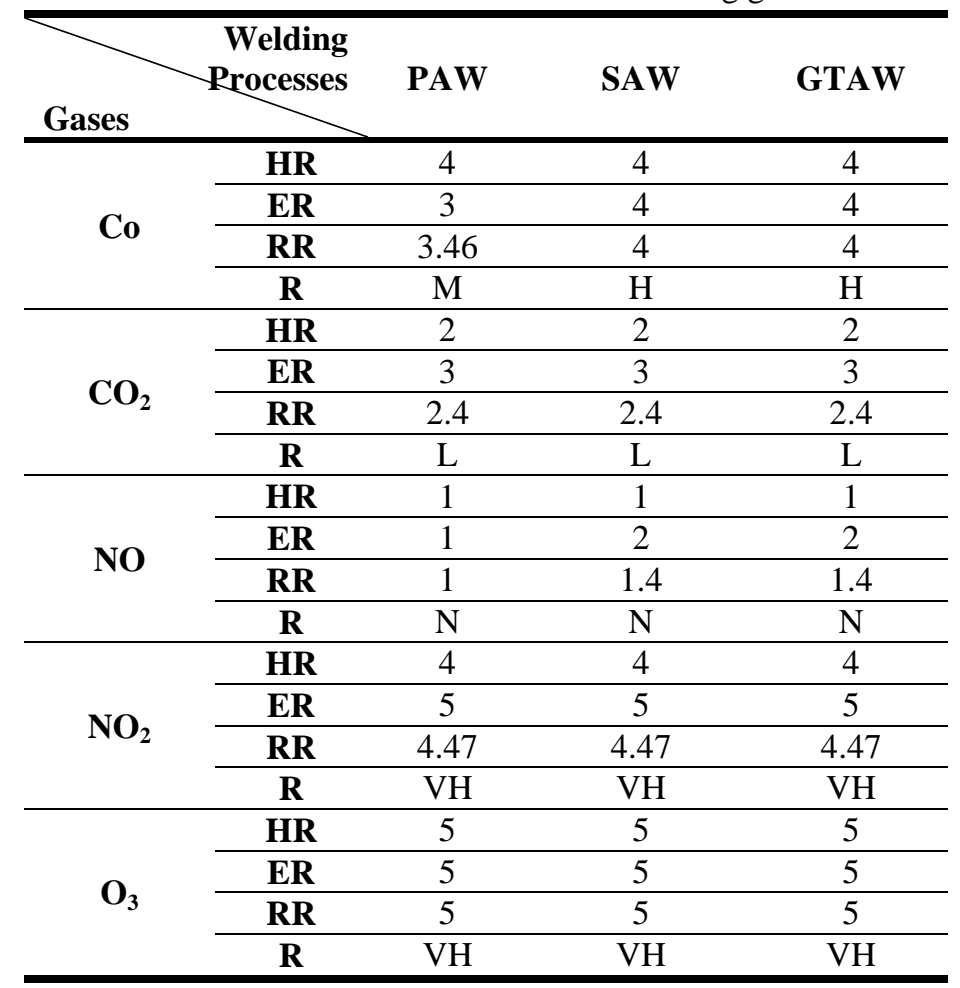

GTAW: Gas tungsten arc welding; SAW: Submerged arc welding; PAW: Plasma arc welding; HR: Hazard rate; ER: Exposure rate; RR: Risk rate

N: Negligible, L: Low, M: Medium, H: High, VH: Very High

\section{Discussion}

Welding gases can induce adverse health effects in welders. Exposure concentrations are important in the assessment of health risks due to exposure to hazardous substances in the workplace. In the present study, the concentrations of gases varied in different welding processes and the lowest exposure was observed in PAW. This may be due to the possible role of welding durations, wind direction, and ambient temperature in welders' exposure to welding gases.

In the current study, exposure to $\mathrm{O}_{3}$ was in the range of $0.16-0.41 \mathrm{ppm}$ in the three of welding processes studied. This level was 3.28.2 times higher than the excursion limit of TLV-TWA (0.05 ppm). However, the studied welders' exposure to welding gases in comparison with TLVs-TWA (ACGIH) was lower (19). Golbabaei et al., in 2015, demonstrated that the range of exposure to $\mathrm{O}_{3}$, $\mathrm{NO}_{2}, \mathrm{CO}$, and $\mathrm{CO}_{2}$ was $0-0.0371,0.01-0.58$, 0.375-4.33, and 89.5-1395.44 ppm, respectively. Among the welders, the back weld group had the maximum exposure to $\mathrm{O}_{3}$, $\mathrm{CO}$, and $\mathrm{CO}_{2}$, while the maximum exposure to $\mathrm{NO}_{2}$ was, respectively, seen in the filling group and back weld group (20). A recent study reported significant decreases in forced vital capacity (FVC), forced expiratory volume-one second $\left(\mathrm{FEV}_{1}\right)$, and forced expiratory flow $\left(\mathrm{FEF}_{25-75}\right)$ and increase in the mental symptom with 2.5 hours of exposure to $\mathrm{O}_{3}$ at $0.12-0.40 \mathrm{ppm}$ (14). The current study showed that the average concentrations of nitrogen dioxide were significantly high during all of the welding processes (Table 1). Brand et al. reported that the cellular effect parameters and macrophage concentration in induced sputum decreased with increasing $\mathrm{NO}_{2}$ concentration with 4 consecutive weeks of exposure at $0.5 \mathrm{ppm}$ (21). Schoonover et al., in a study on production welders and nonwelders, reported that welders were exposed to higher concentrations of $\mathrm{NO}_{2}$ and $\mathrm{O}_{3}$, but this difference was not statistically significant (22). 
Only the exposure concentration of $\mathrm{CO}_{2}$ was lower than TWA-TLV in all welding processes.

A systematic review of the effects of $\mathrm{NO}_{2}, \mathrm{CO}$, and $\mathrm{CO}_{2}$ on human and animal health was conducted by James et al. (23). Karimi et al. reported level of risk derived from sulfuric acid, phosphoric acid, aluminum sulphate, nickel catalyst, acetic acid used as a raw material were $2.4,2.84,2.3,3.5$ and 2.66,respectively. (24). The toxicity of CO has been recognized; thus, its observation and control requires careful consideration. $\mathrm{CO}_{2}$ is a hazard when present in enclosed spaces at high concentrations (25). The results of SQCRA showed that the risk of exposure to $\mathrm{O}_{3}$ and $\mathrm{NO}_{2}$ was very high in all welding processes. In the studied welding processes, the risk of exposure to $\mathrm{NO}$ and $\mathrm{CO}_{2}$ was negligible and low, respectively. The risk assessment results were approximately consistent with results obtained from the measurement of air samples. The results of risk assessment showed, risk managment to help identify and evaluate risks originated from chemicals usages.also risk managment to prevent, reduce, or minimize potential harm to the workplace. Therefore, it is essential that periodic monitoring of gaseous pollutants be carried out regularly in the ambient air of these welding workshops and risk assessment also be carried out regularly on the welders of these workshops to protect them from exposure to welding gases.

\section{Conclusion}

The results of the our study showed that the sampling values of air and method SQRCA were consistent. This indicates that corrective actions should be initiated on welders as soon as possible. It is necessary to apply control approaches in such welding processes. The use of respiratory protection equipment and exhaust ventilation is recommended.

\section{Acknowledgment}

The authors wish to thank Isfahan University of Medical Sciences, Iran, for supporting this research financially, and the welders who participated in this study.

Conflict of interest: None declared

\section{References}

1. Flynn MR, Susi P. Neurological risks associated with manganese exposure from welding operations - a literature review. Int $\mathbf{J}$ Hyg Environ Health 2009; 212(5):459-69.

2. Keane MJ, Siert A, Chen BT, Stone SG. Profiling mild steel welding processes to reduce fume emissions and costs in the workplace. Ann Occup Hyg 2014; 58(4):40312.

3. Popović O, Prokić-Cvetković R, Burzić M, Lukić U, Beljić B. Fume and gas emission during arc welding: hazards and recommendation. Renewable and Sustainable Energy Reviews 2014; 37:509-16.

4. Zamanian Z, Mehrifar Y. Study health and safety workplace in small and medium size enterprises (HSW-SMEs) in Iran. Journal Occupational Health and Epidemiology 2016; 5 (2):112-20.

5. Antonini JM. Health effects of welding. Crit Rev Toxicol 2003; 33(1):61-103.

6. Karimi Zeverdegani S, Barakat S, Yazdi M. Chemical risk assessment in a chemical laboratory based on three different techniques. Journal of Occupational Health and Epidemiology 2016; 5(3):168-75.

7. Pesch B, Weiss T, Kendzia B, Henry J, Lehnert M, Lotz A, et al. Levels and predictors of airborne and internal exposure to manganese and iron among welders. J Expo Sci Environ Epidemiol 2012; 22(3):291-8.

8. Ferreira M. Exposure of welders to manganese in welding fumes [MSc thesis]. Potchefstroom, Mahikeng and Vanderbijlpark, South Africa: North-West University; 2012.

9. Persoons R, Arnoux D, Monssu T, Culié O, Roche G, Duffaud B, et al. Determinants of occupational exposure to metals by gas metal arc welding and risk management measures: A biomonitoring study. Toxicol Lett 2014; 231(2):135-41.

10. Hoet P, Vanmarcke E, Geens T, Deumer G, Haufroid V, Roels HA. Manganese in plasma: a promising biomarker of exposure to $\mathrm{Mn}$ in welders. A pilot study. Toxicol Lett 2012; 213(1):69-74.

11. Liu HH, Wu YC, Chen HL. Production of ozone and reactive oxygen species after welding. Arch Environ Contam Toxicol 2007; 53(4):513-8. 
12. Churg A. Interactions of exogenous or evoked agents and particles: the role of reactive oxygen species. Free Radic Biol Med 2003; 34(10):1230-5.

13. Cheng TJ, Kao HP, Chan CC, Chang WP. Effects of ozone on DNA single-strand breaks and 8-oxoguanine formation in A549 cells. Environ Res 2003; 93(3):279-84.

14. Saito H, Ojima J, Takaya M, Iwasaki T, Hisanaga N, Tanaka S, et al. Laboratory measurement of hazardous fumes and gases at a point corresponding to breathing zone of welder during a $\mathrm{CO} 2$ arc welding. Ind Health 2000; 38(1):69-78.

15. Kiesgen de_Richter R, Ming T, Caillol S. Fighting global warming by photocatalytic reduction of $\mathrm{CO}_{2}$ using giant photocatalytic reactors. Renewable and Sustainable Energy Reviews 2013; 19:82-106.

16. Ayyagari VN, Januszkiewicz A, Nath J. Proinflammatory responses of human bronchial epithelial cells to acute nitrogen dioxide exposure. Toxicology 2004; 197(2):149-64.

17. Papi A, Amadesi S, Chitano P, Boschetto P, Ciaccia A, Geppetti P, et al. Bronchopulmonary inflammation and airway smooth muscle hyperresponsiveness induced by nitrogen dioxide in guinea pigs. Eur $\mathbf{J}$ Pharmacol 1999; 374(2):241-7.

18. Safe Work Australia. Comparison of workers' compensation arrangements in Australia and New Zealand 2012. Australia-New Zealand: Safe Work Australia; 2012. Available from: https://www.safeworkaustralia.gov.au/doc/com parison-workers-compensation-arrangements- australia-and-new-zealand-2012

19. Curran CP, Park RM, Ho SM, Haynes EN. Incorporating genetics and genomics in risk assessment for inhaled manganese: from data to policy. Neurotoxicology 2009; 30(5):75460 .

20. Golbabaei F, Hassani H, Ghahri A, Mirghani $\mathrm{S}$, Arefian $\mathrm{S}$, Khadem $\mathrm{M}$, et al. Risk assessment of exposure to gases released by welding processes in Iranian natural gas transmission pipelines industry. International Journal of Occupational Hygiene 2012; 4(1):69.

21. Brand P, Bertram J, Chaker A, Jörres RA, Kronseder A, Kraus T, et al. Biological effects of inhaled nitrogen dioxide in healthy human subjects. Int Arch Occup Environ Health 2016; 89(6):1017-24.

22. Schoonover T, Conroy L, Lacey S, Plavka J. Personal exposure to metal fume, $\mathrm{NO} 2$, and $\mathrm{O} 3$ among production welders and non-welders. Ind Health 2011; 49(1):63-72.

23. Antonini JM, Lewis AB, Roberts JR, Whaley DA. Pulmonary effects of welding fumes: review of worker and experimental animal studies. Am J Ind Med 2003; 43(4):350-60.

24. Karimi A, Jamshidi Slukloei HR, Eslamizad S. Designing SQCRA as a software to semiquantitative chemical risk assessment in workplace. Journal of Occupational Hygiene Engineering 2014; 1(2):47-56.

25. Scott JL, Kraemer DG, Keller RJ. Occupational hazards of carbon dioxide exposure. Journal of Chemical Health and Safety 2009; 16(2):18-22. 